\title{
Urgensi Keamanan Pangan Rumah Tangga dalam Menghadapi Pandemi Covid-19
}

\section{The Urgency of Household Food Security during the Covid-19 Pandemic}

\author{
Noni Setyorini, Efriyani Sumastuti, Ratih Hesty Utami \\ Program Studi Manajemen, Fakultas Ekonomi dan Bisnis \\ Universitas PGRI Semarang, Semarang \\ *Kontak penulis: nonisetyorini@upgris.ac.id
}

\begin{abstract}
This study aims to examine the urgency of household food safety in the face of the Covid-19 pandemic. The data was collected using an online survey with simple random sampling technique. The number of respondents collected was 135 respondents. Data processing was carried out by SEM-PLS using the SMART PLS software. Based on the results of data processing, household expenditure has an effect on food safety. Nutritional knowledge variables also affect response toward pandemic. Access to food has a negative and significant effect on household expenditure. Household characteristics on access to food also have a significant negative effect. This research provides theoretical and practical contributions which will also be discussed further in this paper.
\end{abstract}

Keywords: Food safety, covid-19, food access, household contest, pandemic response, nutrition knowledge.

\begin{abstract}
Abstrak
Penelitian ini bertujuan untuk mengkaji urgensi keamanan pangan rumah tangga dalam menghadapi pandemi Covid-19. Pengumpulan data dilakukan secara online survey dengan teknik simple random sampling. Jumlah responden yang dikumpulkan adalah 135 responden. Pengolahan data dilakukan dengan SEM-PLS menggunakan software SMART PLS. Berdasarkan hasil pengolahan data, pengeluaran rumah tangga berpengaruh terhadap keamanan pangan. Variabel pengetahuan gizi juga mempengaruhi respon terhadap pandemi. Akses terhadap pangan berpengaruh negatif dan signifikan terhadap pengeluaran rumah tangga. Karakteristik rumah tangga terhadap akses pangan juga berpengaruh negatif signifikan. Penelitian ini memberikan kontribusi teoritis dan praktis yang juga akan dibahas lebih lanjut dalam makalah ini.
\end{abstract}

Keywords: Keamanan pangan, covid-19, akses pangan, pengeluaran rumah tangga, respon pandemic, penegtahuan gizi.

\section{Pendahuluan}

Pangan merupakan makanan dan minuman yang mengandung sumber energi bagi tubuh agar dapat beraktivitas. Pangan merupakan kebutuhan dasar manusia yang paling utama dan pemenuhannya juga merupakan bagian dari hak asasi manusia. Perlindungan masyarakat dari peredaran pangan yang tidak aman merupakan jaminan yang harus didapat masyarakat sebagai konsumen (Lestari, 2020) Hak dasar manusia ini juga sudah dijamin dalam Undang-Undang Dasar Tahun 1945 Pasal 27 ayat (2) yang intinya menyatakan setiap warga negara mempunyai hak untuk mendapatkan penghidupan yang layak sebagai manusia, salah satunya adalah mengonsumsi pangan yang aman dikonsumsi. 
Kondisi yang membahayakan kesehatan dan jiwa konsumen setelah mengkonsumsi pangan yang tidak aman sebagaimana diuraikan di atas, menunjukkan masih lemahnya kedudukan masyarakat sebagai konsumen (Khairati, 2016). Hal ini dikarenakan faktor kurangnya informasi dan pengetahuan tentang pangan yang aman dikonsumsi dan dampak yang dapat terjadi jika mengonsumsi pangan yang tidak aman. Untuk itu, masyarakat perlu mendapat jaminan perlindungan setiap kali membeli produk pangan (Lestari, 2020).

Pangan yang aman haruslah memenuhi gizi yang baik. Status gizi dipengaruhi oleh konsumsi pangan dan aktivitas fisik dari seseorang (Soraya et al., 2017). Konsumsi pangan merupakan faktor utama dalam memenuhi kebutuhan zat gizi di dalam tubuh. Zat gizi berfungsi sebagai sumber tenaga bagi tubuh, mengatur proses metabolisme dalam tubuh, memperbaiki jaringan tubuh serta pertumbuhan (Irnani \& Sinaga, 2017). Pemilihan bahan pangan dan penentuan jumlah makanan yang dikonsumsi dipengaruhi oleh pengetahuan gizi. Pengetahuan gizi merupakan aspek kognitif yang menunjukkan pemahaman tentang ilmu gizi, jenis zat gizi, serta interaksinya terhadap status gizi dan kesehatan. Pengetahuan tentang gizi merupakan salah satu hal yang mempengaruhi status gizi secara tidak langsung dan merupakan landasan dalam menentukan konsumsi makanan (Soraya et al., 2017).

Dewan Ketahanan Pangan (DKP) bersama World Food Program (WFP) telah merumuskan indikator-indikator ketahanan pangan yang dikelompokkan ke dalam tiga faktor, yaitu faktor ketersediaan, akses, dan pemanfaatan pangan. Dengan demikian, dapat dikatakan bahwa sistem ketahanan pangan terdiri dari tiga subsistem utama yaitu ketersediaan, akses, dan penyerapan pangan (Nur Intania Sofianita1*, Firlia Ayu Arini1, 2015). Ketersediaan pangan harus mampu mencukupi pangan yang didefinisikan sebagai jumlah kalori yang dibutuhkan untuk kehidupan yang aktif dan sehat (Suryana, 2014). Sedangkan akses pangan adalah kemampuan semua rumah tangga dan individu dengan sumber daya yang dimilikinya untuk memperoleh pangan yang cukup untuk kebutuhan gizinya . Akses pangan meliputi akses ekonomi, fisik, dan sosial. Akses ekonomi tergantung pada pendapatan, kesempatan kerja, dan harga. Akses fisik menyangkut tingkat isolasi daerah (sarana dan prasarana distribusi), sedangkan akses sosial menyangkut tentang preferensi pangan. Sedangkan penyerapan pangan adalah penggunaan pangan untuk kebutuhan hidup sehat yang meliputi kebutuhan energi dan gizi, air, dan kesehatan lingkungan (Pujiati et al., 2020).

Kemampuan untuk mampu mengakases pangan juga dipengaruhi oleh karakteristik rumah tangga. Karakteristik rumah tangga terdiri dari pendidikan, pendapatan dan pengeluaran rumah tangga. Semakin tinggi pendapatan yang diterima masyarakat maka ia akan mampu membiayai pengeluaran rumah tangganya sehingga ia akan memiliki akses pangan rumah tangga. Sehingga meskipun dalam kondisi pandemic covid-19, kondisi pangan rumah tangga tetap terjaga keamanannya (Supadi \& Nurmanaf, 2006).

Kondisi pandemi COVID-19 ini mengakibatkan akses terhadap makanan akan diperparah dengan semakin memburuknya pandemi itu sendiri serta laranganlarangan perpindahan penduduk yang mengikutinya. Hal ini juga sesuai dengan dengan (Burgui-Burgui \& Chuvieco, 2020), yang menyatakan bahwa wabah suatu penyakit yang terjadi di dunia akan meningkatkan jumlah penduduk yang mengalami kelaparan dan malnutrisi. Kondisi tersebut disebabkan oleh kualitas gizi yang kurang mengingat jumlah pasokan pangan yang terbatas. Disamping itu, pada masa Covid-19, 
rumah tangga akan memberikan respon yang berbeda-beda. Respon ini sangat penting dan menentukan bagaimana rumah tangga memenuhi kebutuhan pangan sehari-hari.

\section{Kajian Literatur}

\section{a. Karakteristik Rumah Tangga}

Rumah tangga merupakan pelaku ekonomi terkecil.Namun demikian, rumah tangga merupakan pelaku ekonomi terpenting karena semua kegiatan ekonomi berawal dari rumah tangga. Seluruh kegiatan ekonomi yang mencakup produksi, distribusi dan konsumsi pasti melibatkan salah satu anggota keluarga. Karakteristik rumah tangga yang terdiri dari umur, pendidikan kepala keluarga, jenis pekerjaan, pendapatan, jumlah anggota keluarga yang bekerja, kesehatan, suku/etnis, kondisi rumah dan fasilitas rumah diduga berpengaruh terhadap tingkat kemiskinan rumah tangga.

b. Pengetahuan Gizi

Pengetahuan gizi adalah pemahaman seseorang tentang ilmu gizi, zat gizi, serta interaksi antara zat gizi terhadap status gizi dan kesehatan (Nova \& Yanti, 2018). Pengetahuan yang didasari dengan pemahaman yang tepat akan menumbuhkan perilaku yang diharapkan, khususnya tentang pengetahuan gizi (Soraya et al., 2017). Jika pengetahuan individu kurang tentang gizi, maka upaya yang dilakukan individu untuk menjaga keseimbangan makanan yang dikonsumsi dengan yang dibutuhkan akan berkurang dan menyebabkan masalah gizi kurang atau gizi lebih (Sumartini, 2019).

Masyarakat mampu maupun tidak mampu di Indonesia memiliki pengetahuan tentang gizi seimbang yang masih kurang. Sehingga saat pemenuhan gizi seimbang tak tercapai, masyarakat yang mampu juga bisa mengalami kekurangan ataupun kelebihan gizi (Vita Muniarti Tarawan, Ronny Lesmana, Hanna Gunawan, 2019) . Hal ini mengindikasikan bahwa tingkat pengetahuan gizi pada individu di Indonesia masih tergolong rendah sehingga sikap mereka terhadap pemilihan makanan yang bergizi masih kurang.

c. Pengeluaran Rumah Tangga

Nurhadi (2005:78) dalam (Wahyuni, 2013) konsumsi adalah kegiatan manusia menggunakan atau memakai barang atau jasa untuk memenuhi kebutuhan. Mutu dan jumlah barang atau jasa dapat mencerminkan kemakmuran konsumen tersebut. Semakin tinggi mutu dan semakin banyak jumlah barang atau jasa yang dikonsumsi, berarti semakin tinggi pula tingkat kemakmuran konsumen yang bersangkutan sebaliknya semakin rendah mutu kualitas dan jumlah barang atau jasa yang dikonsumsi, berarti semakin rendah pula tingkat kemakmuran konsumen yang bersangkutan (Hanum, 2018). Tujuan konsumsi adalah untuk mencapai kepuasan maksimum dari kombinasi barang atau jasa yang digunakan. Individu meminta suatu komoditi tertentu karena kepuasan yang diterima dari mengkonsumsi suatu barang. Sampai pada titik tertentu, semakin banyak unit komoditi yang dikonsumsi individu tersebut per unit waktu, akan semakin besar utiliti total yang akan diterima. Dari sisi lain Samuelson berpendapat bahwa apabila harga meningkat dan pendapatan nominal tetap, maka pendapatan riil akan menurun, maka konsumen akan mengurangi pembelian hampir semua jenis barang (Wahyuni, 2013).

d. Akses Pangan

Akses pangan adalah kemampuan semua rumah tangga dan individu dengan sumber daya yang dimilikinya untuk memperoleh pangan yang cukup untuk kebutuhan 
gizinya. Akses pangan meliputi akses ekonomi, fisik, dan sosial. Akses ekonomi tergantung pada pendapatan, kesempatan kerja, dan harga (Pujiati et al., 2020; Rachmaningsih \& Priyarsono, 2012). Akses fisik menyangkut tingkat isolasi daerah (sarana dan prasarana distribusi), sedangkan akses sosial menyangkut tentang preferensi pangan (Mun'im, 2012). Terdapat enam indikator akses pangan yang harus dipertimbangkan untuk dilakukan monitoring dan pemilihan indikator terkait dengan intervensi program yaitu: 1) Akses pangan rumah tangga tidak cukup untuk melihat akses pangan tingkat individu dalam rumah tangga tersebut, karena rumah tangga sebagai kelembagaan sosial berkaitan dengan akses pangan individu. Sehingga seharusnya ada data distribusi pangan dalam rumah tangga; 2) Akses pangan adalah kebutuhan akan tetapi kondisi ini tidak cukup untuk menentukan penggunaan/konsumsi pangan oleh semua anggota rumah tangga. Hal ini terkait dengan aspek pemeliharaan kesehatan. Jika rumah tangga mempunyai sumber daya yang cukup untuk pangan semua anggota rumah tangga, namun belum tentu setiap anggota tersebut secara aktual akan menerima dan menggunakan sesuai dengan kecukupannya. Makanan yang didistribusikan secara kuantitas dan kualitas pangan harus berdampak pada kesehatan anggota tersebut; 3) Akses pangan tergantung dari pendapatan yang diperoleh oleh rumahtangga secara relatif dengan harga panga (daya beli); 4) Rumahtangga memiliki berbagai strategi untuk memperoleh pendapatan. Rumahtangga memiliki akses berbagai sumber daya seperti tenaga kerja, lahan, ternak, dan modal (Suharyanto, 2011).

e. Respon terhadap pandemic Covid-19.

Menurut KBBI (Kamus Besar Bahasa Indonesia) respon adalah kemampuan untuk memberikan tanggapan maupun reaksi atas apa yang terjadi pada seseorang. Adapun objek nya adalah pandemic covid-19. Virus corona 2019 (corona virus disease/Covid 19) nama yang baru diberikan World Health Organization (WHO) bagi pasien dengan infeksi virus novel corona 2019 yang pertama kali dilaporkan di kota Wuhan, Cina akhir 2019 (Susilo et al., 2020). Penyebaran terjadi dengan cepat dan membuat ancaman pandemic baru. Didasarkan kondisi tersebut maka individu harus memberikan respon atas himbauan dan kebijakan yang diberikan oleh pemerintah dengan mengikuti aturan yang ditetapkan untuk mengurangi penyebaran virus covid-19.

Penelitian sebelumnya oleh Sudiro dan Watimena (2020) mengenai sikap dan perilaku masyarakat Indonesia terhadap pandemic virus (Covid 19) di Indonesia bahwa masyarakat menunjukan emosional sedih, takut terhadap kondisi saat ini. Penelitian serupa telah dilakukan di Bali oleh (Lina Rahmawati, Riyanto, n.d.)bekerjasama dengan PPNI setempat mengenai gambaran perilaku masyarakat tentang Covid-19 dan perilaku masyarakat dimasa Pandemi Covid 19 hasil nya bahwa pengetahuan masyarakat mengenai hal tersebut baik yaitu 70\%. Masyarakat Bali menunjukan kepatuhan terhadap protocol kesehatan dimasa pandemic Covid 19. Kategori kasus masyarakat sebagian besar beresiko rendah (85,33\%) mengalami Covid 19.

\section{f. Keamanan Pangan}

Menurut WHO, keamanan pangan (food safety) adalah suatu ilmu yang membahas tentang persiapan, penanganan, dan penyimpanan makanan atau minuman agar tidak terkontaminasi oleh bahan fisik, biologi, dan kimia. Tujuan utama keamanan pangan adalah untuk mencegah makanan dan minuman agar tidak terkontaminasi oleh zat asing baik fisik, biologi, maupun kimia sehingga dapat mengurangi potensi terjadinya sakit akibat bahaya pangan. Kontaminasi fisik adalah benda asing yang masuk ke 
dalam makanan atau minuman. Contohnya rambut, logam, plastik, kotoran, debu, kuku, dan lainnya. Arti dari kontaminasi biologi adalah suatu zat yang diproduksi oleh makhluk hidup (seperti manusia, tikus, kecoa, dan lainnya) yang masuk ke dalam makanan atau minuman.

\section{Metode Penelitian}

Penelitian yang akan dilakukan menggunakan metode penelitian kuantitatif. Penelitian kuantitaif merupakan penelitian yang berlandaskan pada filsafat positivisme, dan digunakan untuk meneliti pada populasi atau sampel tertentu. Teknik pengambilan sampel dilakukan secara random. Pengumpulan data menggunakan instrumen penelitian survei, berupa kuesioner. Kuesioner yang dirancang dengan pernyataan tertutup bertujuan agar mudah dalam proses koding serta analisis jawaban dari responden. Oleh karena itu, dalam proses pendistribusian kuesioner dengan menggunakan metoda self-administered survey questionnaire, suatu metoda survei yang dikelola sendiri. Dalam studi ini, peneliti mendistribusikan sendiri kuesioner penelitian kepada responden pada masing-masing objek penelitian.

Data yang dipergunakan dalam penelitian ini menggunakan data primer. Data primer merupakan data yang langsung didapatkan dari responden atau orang pertama. Sekaran (2006) menyatakan data primer adalah data yang diperoleh secara langsung oleh peneliti dengan menanyakan responden, mengamati peristiwa, atau melalui pembagian daftar pertanyaan. Jawaban responden merupakan sumber data primer yang didapat oleh peneliti berdasarkan pembagian kuesioner kepada responden. Data penelitian ini menggunakan data cross sectional yang didapat melaui survei. Sekaran (2006) menyatakan bahwa cross sectional study yaitu suatu studi yang mengumpulkan data dalam satu titik waktu untuk menjawab pertanyaan penelitian. Penelitian ini menggunakan metode accidental sampling.

Pengujian instrument dilakukan sebelum melakukan pengujian hipotesis. Pengujian instrument dilakukan dengan menggunakan uji reliabilitas dan uji validitas. Uji validitas mengukur seberapa baik indikator empiris dan definisi konseptual dari konstruk yang diukur yang ditujukan untuk diukur "fit" secara bersama (Neuman, 2006). Uji validitas digunakan untuk mengetahui kelayakan butir-butir pernyataan pada angket. Pengujian validitas pada penelitian ini terdiri dari dua parameter, yaitu validitas konvergen dan validitas diskriminan.

Uji validitas konvergen didasarkan pada loading dengan rule of thumb untuk mengukur loading yaitu, loading 0,50 dianggap signifikan secara praktik (Hair et al., 2010). Uji validitas diskriminan dinilai dengan cara membandingkan akar kuadrat dari average variance extracted (AVE) dengan korelasi antar konstruk, atau dapat membandingkan loading konstruk yang diukur dengan loading konstruk yang lainnya (Sholihin dan Ratmono, 2013).

Reliabilitas merupakan ukuran suatu kestabilan dan konsistensi responden dalam menjawab kuesioner. Suatu kuesioner dikatakan reliabel atau handal jika jawaban seseorang terhadap pernyataan adalah konsisten atau stabil dari waktu ke waktu (Neuman, 2006). Uji reliabilitas dinilai berdasarkan pada composite reliability dan cronbach alpha. Menurut Hair et al. (2010) bahwa rule of thumb uji reliabilitas yaitu koefisien dengan nilai $\leq 0,60$ menunjukkan hasil uji reliabilitas dinilai buruk, tapi masih dapat digunakan untuk analisis selanjutnya. Kemudian, koefisien menunjukkan nilai antara 0,60 sampai dengan 0,70 maka reliabilitas dapat diterima, selanjutnya jika 
koefisien dengan nilai $\geq 0,80$ maka reliabilitas dinilai baik. Teknik analisis pada sebuah penelitian perlu diperhatikan karena dengan teknik yang benar maka hasil yang didapatkan akan benar. Gudono (2014) menyatakan bahwa SEM dibutuhkan ketika hubungan variabel yang kompleks, terdapat variabel laten, dan ingin menguji fitness secara keseluruhan. Manfaat utama SEM dibandingkan dengan multivariate generasi pertama seperti principal component analysis, factor analysis, discriminant analysis atau multiple regression adalah SEM memiliki fleksibilitas yang lebih tinggi bagi peneliti untuk menghubungkan teori dan data.

SEM dapat berbasis pada dua hal, yaitu berbasis covariance yang diwakili oleh software AMOS dan LISREL serta SEM yang berbasis variance atau yang sering disebut Partial Least Square (PLS) dengan software antara lain SmartPLS, PLS Graph. Wold (1985) dalam Gudono (2014) mengatakan bahwa Partial Least Square (PLS) merupakan metoda analisis yang kuat karena dapat diterapkan pada semua skala data dan tidak membutuhkan banyak asumsi. Adapun proses pengujian menggunakan software SmartPLS 3.0.

\section{Hasil dan Pembahasan}

\section{Hasil Penelitian}

Jumlah total responden dalam penelitian ini berjumlah 135 responden. Adapun karakteristik umur di dominasi oleh responden dengan usia diatas 41 tahun, dengan status pernikahan menikah. Adapun tingkat pendidikan rata-rata adalah sarjana. 
Tabel 1

Karakteristik responden

\begin{tabular}{lcl}
\hline Deskripsi Responden & Frekuensi & Persentase(\%) \\
\hline Jenis Pekerjaan & & \\
ASN & 20 & $14.8 \%$ \\
Non ASN & 115 & $85.2 \%$ \\
Total & 135 & $100 \%$ \\
Kategori Umur & & \\
<25tahun & & \\
26-30tahun & 30 & $21.5 \%$ \\
$31-35 t a h u n$ & 17 & $12.6 \%$ \\
36-40tahun & 11 & $8.1 \%$ \\
$>41$ tahun & 15 & $11.1 \%$ \\
Total & 63 & $46.7 \%$ \\
Status Pernikahan & 135 & $100 \%$ \\
Menikah & & \\
Belum menikah & 95 & $70.4 \%$ \\
Janda/Duda & 36 & $26.7 \%$ \\
Total & 4 & $3 \%$ \\
Tingkat Pendidikan & 135 & $100 \%$ \\
SMA/SMK & & \\
Diploma & 28 & $20.7 \%$ \\
S-1 & 6 & $4.4 \%$ \\
S-2 & 46 & $34,1 \%$ \\
S-3 & 50 & $37 \%$ \\
\hline Total & 5 & $3.7 \%$ \\
\hline
\end{tabular}

Proses pengolahan data dalam penelitian ini dilakukan menggunakan analisis SEM-PLS menggunakan software Smart.PLS. Adapun hasil pengujian hipotesis dalam penelitian ini adalah sebagai berikut :

Tabel 2.

Hasil Pengujian Hipotesis

\begin{tabular}{lllll}
\hline Variabel Penelitian & Original & T & \multicolumn{2}{l}{ P value Hasil } \\
\hline Akses => Pengeluaran Rumah Tangga & -0.273 & 2.684 & 0.008 & Diterima \\
Karakteristik Rumah tangga => Akses & -0.283 & 2.899 & 0.000 & Diterima \\
Karakteristik Rumah tangga => Respon & -0.164 & 1.238 & 0.216 & Ditolak \\
Pengeluaran Rumah Tangga => & -0.327 & 4.202 & 0.000 & Diterima \\
Pengetahuan Gizi => akses pangan & 0.021 & 0.151 & 0.880 & Ditolak \\
Pengetahuan Gizi => respon & 0.528 & 3.317 & 0.001 & Diterima \\
Respon=> Pengeluaran Rumah Tangga & -0.084 & 0.683 & 0.495 & Ditolak \\
& & & & \\
\hline
\end{tabular}




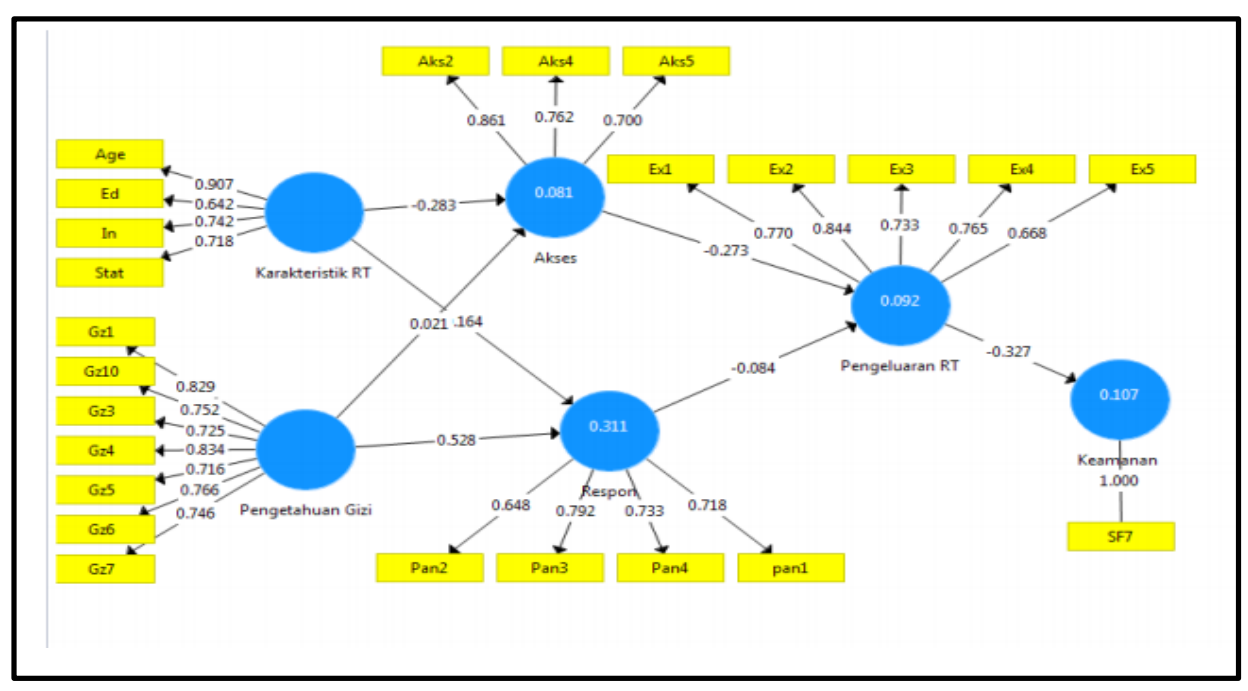

Gambar 1. Hasil Analisis PLS

Berdasarkan hasil olah data tersebut diketahui hipotesis 1, yaitu akses pangan berpengaruh negatif dan signifikan terhadap pengeluaran rumah tangga dengan nilai path coefficient -0.273 dan $t$ value 2.684 pada a $1 \%$. Hal tersebut berarti semakin tinggi akses pangan maka pengeluaran rumah tangga semakin rendah. Hipotesis 2, karakteristik rumah tangga berpengaruh negatif dan signifikan terhadap akses dengan nilai path coefficient -0.283 , $\mathrm{t}$ value 2.899 pada a $1 \%$. Hipotesis ini menunjukkan bahwa semakin tinggi karakteristik rumah tangga maka akses semakin rendah. Hipotesis 3, menyatakan bahwa karakteristik rumah tangga tidak berpengaruh terhadap respon. Hipotesis 4, pengeluaran tumah tangga berpengaruh secara negatif dan signifikan terhadap keamanan pangan. Nilai path coefficient 0.327 dan $t$ value 4.202 pada a $1 \%$. Didasarkan hasil pengujian tersebut maka semakin tinggi pengeluaran rumah tangga maka keamanan semakin rendah. Hipotesis 5, dinyatakan bahwa pengetahuan gizi tidak berpengaruh terhadap akses pangan. Hipotesis 6 menyatakan bahwa pengetahuan gizi berpengaruh secara positif dan signifikan terhadap respon, dengan nilai path coefficient 0.528 , $\mathrm{t}$ value 3.317 pada a $1 \%$. Hipotesis ini menunjukkan bahwa semakin tinggi pengetahuan gizi maka respon semakin tinggi. Hipotesis 7, dinyatakan bahwa respon pandemi tidak berpengaruh terhadap pengeluaran rumah tangga.

\section{Pembahasan}

Pandemi Covid-19 memberikan dampak pada perubahan perilaku dan aktivitas ekonomi masyarakat, sehingga menimbulkan adanya dorongan terhadap peningkatan angka kemiskinan (BPS, 2020). Hasil hipotesis 1 menjelaskan bahwa akses pangan berpengaruh negatif dan signifikan terhadap pengeluaran rumah tangga Perlambatan ekonomi masyarakat menyebabkan rumah tangga pada lapisan ini kesulitan untuk memenuhi kebutuhan hidup, sehingga konsumsi rumah tangganya pun menurun, karena kemampuan daya beli yang menurun (Barany et al, 2020; TNP2K, 2020). Dampak terburuk pandemi dapat menyebabkan akses pangan keluarga miskin semakin terbatas yang dapat mengancam ketahanan pangan (TNP2K, 2020). Karakteristik rumah tangga berpengaruh negatif dan signifikan terhadap akses. 
Dampak terburuk akibat pandemic memukul lapisan rumah tangga yang sumber pendapatannya berasal dari pekerja sektor informal (Maftuchan, 2020; Barany et al, 2020; BPS, 2020). Dampak pandemi telah menurunkan besaran pengeluaran konsumsi pangan keluarga miskin akibat pendapatan menurun dan keterlambatan bansos pemerintah. Keluarga miskin terancam rawan pangan, karena akses pangannya menjadi terbatas di saat ketersediaan kasnya menurun.

Sedangkan karakteristik rumah tangga tidak berpengaruh terhadap respond terhadap pandemic. Hal tersebut diduga karena penelitian ini memiliki keberagaman responden dengan perbedaan latar belakang pendidikan, ekonomi, dan sosial. Oleh karena itu proses dalam merespon kondisi pandemic akan berbeda-beda tergantung dari tingkat pendidikan, pengetahuan, ekonomi dan sosial.

Pengeluaran tumah tangga berpengaruh secara negatif dan signifikan terhadap keamanan pangan. Keluarga miskin terancam rawan pangan, karena akses pangannya menjadi terbatas di saat ketersediaan kasnya menurun. Jika kas untuk membeli persediaan bahan baku tidak ada maka hal tersebut akan membuat masyarakat kurang mampu untuk memilih makanan dengan keamanan yang baik dan terjamin.

Pengetahuan gizi tidak berpengaruh terhadap akses pangan, namun pengetahuan gizi berpengaruh secara positif dan signifikan terhadap respon. Pengetahuan merupakan domain yang sangat penting untuk terbentuknya tindakan seseorang. Apabila penerimaan perilaku baru didasari oleh pengetahuan, kesadaran dan sikap yang positif, maka perilaku tersebut akan bersifat langgeng. Sebaliknya apabila tidak didasari oleh pengetahuan dan kesadaran maka tidak akan langsung lama. Pengetahuan gizi tidak berpengaruh terhadap akses pangan karena pengetahuan tidak akan membantu perilaku dalam menentukan pilihan pangan dan akses untuk mendapatkan kebutuhan pangan. Meskipun, pengetahuan gizi diketahui berpengaruh terhadap respon terhadap pandemic. Karena pengetahuan gizi akan membuat masyarakat menyadari pentingnya mempertahankan imunitas tubuh sehingga akan berusaha untuk memberikan respon positif terhadap pandemic dengan memenuhi kebutuhan harian yang bergizi.

Respon pandemi tidak berpengaruh terhadap pengeluaran rumah tangga. Hal tersebut karena respon pandemic tidak selalu dalam bentuk pengeluaran rumah tangga namun juga berupa tindakan sehari-hari yang bersifat non ekonomi. Sehingga perlu dilihat dari sudut pandang non ekonomi.

\section{Kesimpulan}

Berdasarkan hasil penelitian diketahui bahwa kemanan pangan adalah hal yang harus diperhatikan. Pengeluaran rumah tangga untuk konsumsi disebutkan memiliki pengaruh terhadap keamanan pangan. Hal tersebut karena alokasi keuangan untuk konsumsi akan mengarahkan pada kualitas pangan yang baik. pengetahuan gizi juga menjadi hal penting terhadap respon pangan karena memiliki pengaruh yang paling tinggi. Hal tersebut karena keinginan manusia untuk mampu memenuhi kebutuhan panggannya dengan kualitas yang baik. Sedangkan akses pangan berpengaruh negative dan signifikan terhadap pengeluaran rumah tangga. Karakteristik rumah tangga terhadap akses pangan juga berpengaruh negative 
signifikan. Adapun saran penelitian ini adalah bahwa pemerintah harus selalu menjaga keamanan pangan yang dikonsumsi masyarakat karena kebutuhan pangan merupakan kebutuhan dasar manusia. Sedangkan saran penelitian mendatang adalah untuk melakukan penelitian secara kualitatif agar mendapatkan hasil temuan yang lebih dalam.

\section{Daftar Pustaka}

Burgui-Burgui, M., \& Chuvieco, E. (2020). Beyond carbon footprint calculators. New approaches for linking consumer behaviour and climate action. Sustainability (Switzerland), 12(16). https://doi.org/10.3390/su12166529

Hanum, N. (2018). Pengaruh Pendapatan, Jumlah Tanggungan Keluarga Dan Pendidikan Terhadap Pola Konsumsi Rumah Tangga Nelayan Di Desa Seuneubok Rambong Aceh Timur. Jurnal Samudra Ekonomika, 2(1), 75-84. https://ejurnalunsam.id/index.php/jse/article/view/779

Irnani, H., \& Sinaga, T. (2017). Pengaruh pendidikan gizi terhadap pengetahuan praktik gizi seimbang dan status gizi pada anak sekolah dasar. Jurnal Gizi Indonesia (The Indonesian Journal of Nutrition), 6(1), 58-64. https://doi.org/10.14710/jgi.6.1.58-64

Khairati, R. (2016). RESPONSE OF FOOD DEMAND TO POPULATION Pembagian

Urusan Pemerintah antara. Jurnal Pembangunan Nagari, 1(2), 19-36.

Lestari, T. R. P. (2020). Keamanan Pangan Sebagai Salah Satu Upaya Perlindungan Hak Masyarakat Sebagai Konsumen. Aspirasi: Jurnal Masalah-Masalah Sosial, 11(1), 57-72. https://doi.org/10.46807/aspirasi.v11i1.1523

Lina Rahmawati, Riyanto, A. (n.d.). Community Response Regarding Covid 19 in Indramayu West Java. Stikesindramayu. https://www.ojs.stikesindramayu.ac.id/index.php/JKIH/article/view/296

Mun'im, A. (2012). Analisis Pengaruh Faktor Ketersedian, Akses, dan Penyerapan Pangan terhadap Ketahanan Pangan di Kabupaten Surplus Pangan : Pendekatan Partial Least Square Path Modeling. Jurnal Agro Ekonomi, 6(2), 41-58.

Nova, M., \& Yanti, R. (2018). Hubungan Asupan Zat Gizi Makro dan Pengetahuan Gizi dengan Status Gizi pada Siswa MTs.S AN-Nur Kota Padang. JURNAL KESEHATAN PERINTIS (Perintis's Health Journal), 5(2), 169-175.

Nur Intania Sofianita1* , Firlia Ayu Arini1, E. M. (2015). Peran Pengetahuan Gizi Dalam Menentukan Kebiasaan Sarapan Anak-Anak Sekolah Dasar Negeri Di Pondok Labu, Jakarta Selatan. Jurnal Gizi Dan Pangan, 10(1), 57-62. https:// doi.org/10.25182/jgp.2015.10.1.

Pujiati, S., Pertiwi, A., Silfia, C. C., Ibrahim, D. M., \& Nur Hafida, S. H. (2020). Analisis Ketersediaan, Keterjangkauan Dan Pemanfaatan Pangan Dalam Mendukung Tercapainya Ketahanan Pangan Masyarakat Di Provinsi Jawa Tengah. Jurnal Sosial Ekonomi Pertanian, 16(2), 123. https://doi.org/10.20956/jsep.v16i2.10493

Retherford, R. D., \& Choe, M. K. (1993). Multiple regression. Statistical models for causal analysis, 29-68.

Rachmaningsih, T., \& Priyarsono, D. S. (2012). Ketahanan Pangan di Kawasan Timur 
Indonesia. Jurnal Ekonomi Dan Pembangunan Indonesia, 13(1), 1-18. https://doi.org/10.21002/jepi.v13i1.225

Soraya, D., Sukandar, D., \& Sinaga, T. (2017). Hubungan pengetahuan gizi, tingkat kecukupan zat gizi, dan aktivitas fisik dengan status gizi pada guru SMP. Jurnal Gizi Indonesia (The Indonesian Journal of Nutrition), 6(1), 29-36. https://doi.org/10.14710/jgi.6.1.29-36

Streiner, D. L. (2005). Finding our way: An introduction to path analysis. Canadian Journal of Psychiatry, 50(2), 115-122. https:/ / doi.org/10.1177/070674370505000207

Supadi, \& Nurmanaf, A. R. (2006). Pendapatan Dan Pengeluaran Rumah Tangga Pedesaan Dan Kaitannya Dengan Tingkat Kemiskinan. SOCA: Socioeconomics of Agriculture and Agribusiness, 6(3), 1-19.

Suryana, A. (2014). Menuju Ketahanan Pangan Indonesia Berkelanjutan 2025: Tantangan dan Penanganannya. Forum Penelitian Agro Ekonomi, 32(2), 123. https:/ / doi.org/10.21082/fae.v32n2.2014.123-135

Hanum, N. (2018). Pengaruh Pendapatan, Jumlah Tanggungan Keluarga Dan Pendidikan Terhadap Pola Konsumsi Rumah Tangga Nelayan Di Desa Seuneubok Rambong Aceh Timur. Jurnal Samudra Ekonomika, 2(1), 75-84. https:/ / ejurnalunsam.id/index.php/jse/article/view/779

Lina Rahmawati, Riyanto, A. (n.d.). Community Response Regarding Covid 19 in Indramayu West Java. Stikesindramayu. https:/ / www.ojs.stikesindramayu.ac.id/index.php/JKIH/article/view/296

Mun'im, A. (2012). Analisis Pengaruh Faktor Ketersedian, Akses, dan Penyerapan Pangan terhadap Ketahanan Pangan di Kabupaten Surplus Pangan : Pendekatan Partial Least Square Path Modeling. Jurnal Agro Ekonomi, 6(2), 41-58.

Nova, M., \& Yanti, R. (2018). Hubungan Asupan Zat Gizi Makro dan Pengetahuan Gizi dengan Status Gizi pada Siswa MTs.S AN-Nur Kota Padang. JURNAL KESEHATAN PERINTIS (Perintis's Health Journal), 169-175. https://doi.org/10.33653/jkp.v5i2.145

Pujiati, S., Pertiwi, A., Silfia, C. C., Ibrahim, D. M., \& Nur Hafida, S. H. (2020). Analisis Ketersediaan, Keterjangkauan Dan Pemanfaatan Pangan Dalam Mendukung Tercapainya Ketahanan Pangan Masyarakat Di Provinsi Jawa Tengah. Jurnal Sosial Ekonomi Pertanian, 16(2), 123. https://doi.org/10.20956/jsep.v16i2.10493

Rachmaningsih, T., \& Priyarsono, D. S. (2012). Ketahanan Pangan di Kawasan Timur Indonesia. Jurnal Ekonomi Dan Pembangunan Indonesia, 13(1), 1-18. https://doi.org/10.21002/jepi.v13i1.225

Soraya, D., Sukandar, D., \& Sinaga, T. (2017). Hubungan pengetahuan gizi, tingkat kecukupan zat gizi, dan aktivitas fisik dengan status gizi pada guru SMP. Jurnal Gizi Indonesia (The Indonesian Journal of Nutrition), 6(1), 29-36. https:/ / doi.org/10.14710/jgi.6.1.29-36

Sudiro, A., \& Watimena, L. (2020). Sikap dan Prilaku Masyarakat Indonesia Terhadap Pandemi Virus Corona ( Covid-19) di Indonesia dideklarasikan sebagai Keadaan Darurat Kesehatan Masyarakat Perhatian Internasional atau Public Health Emergency 
of International Concern ( PHEIC ) oleh World H. Jurnal Kedokteran Dan Kesehatan, 7(3), $1-7$.

Suharyanto, H. (2011). KETAHANAN PANGAN. Sosial Humaniora, 4(2), 186-194. http://iptek.its.ac.id/index.php/jsh/article/view/633/355

Sumartini, S. (2019). Hubungan Pengetahuan Gizi, Pola Konsumsi Dan Raihan Nilai Pada Matakuliah Ilmu Gizi Pangan Mahasiswa Prodi Teknologi Pangan Fakultas Teknik Unpas Bandung. Pasundan Food Technology Journal, 6(1), 31. https://doi.org/10.23969/pftj.v6i1.1509

Susilo, A., Rumende, C. M., Pitoyo, C. W., Santoso, W. D., Yulianti, M., Herikurniawan, H., Sinto, R., Singh, G., Nainggolan, L., Nelwan, E. J., Chen, L. K., Widhani, A., Wijaya, E., Wicaksana, B., Maksum, M., Annisa, F., Jasirwan, C. O. M., \& Yunihastuti, E. (2020). Coronavirus Disease 2019: Tinjauan Literatur Terkini. Jurnal Penyakit Dalam Indonesia, 7(1), 45. https:/ / doi.org/10.7454/jpdi.v7i1.415

Vita Muniarti Tarawan, Ronny Lesmana, Hanna Gunawan, J. W. G. (2019). Hubungan Antara Pola Konsumsi dan Tingkat Pengetahuan Mengenai Gizi Seimbang pada Warga Desa Cimenyan. Jurnal Pengabdian Kepada Masyarakat ISSN 1410-5675 ; EISSN 2620-8431, 4(2), 129-132. http://jurnal.unpad.ac.id/pkm/article/view/26643/13802

Wahyuni, S. (2013). Teori Konsumsi Dan Produksi Dalam Perspektif Islam. Jurnal Akuntabel, Vol 10(No 1), 74-79. https:/ / core.ac.uk/download/pdf/229018574.pdf 